
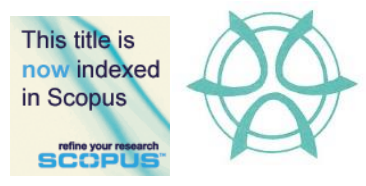

PLANNING MALAYSIA:

Journal of the Malaysian Institute of Planners

VOLUME 16 ISSUE 2 (2018), Page 119 - 130

\title{
FACTOR ANALYSIS ON HEDONIC PRICING MODEL ON OPEN SPACE AFFECTING THE HOUSING PRICE IN MELAKA AND SEREMBAN
}

\author{
M. Zainora Asmawi ${ }^{1}$, Mohammad Abdul Mohit ${ }^{2}$, Norzailawati Mohd.

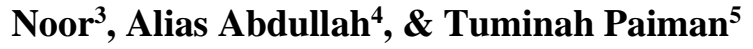 \\ ${ }^{1-5}$ Kulliyyah of Architecture and Environmental Design, \\ INTERNATIONAL ISLAMIC UNIVERSITY MALAYSIA
}

\begin{abstract}
Open spaces near residential area often labelled as development constraint since each residential development must provide 10 percent of open space from the total acreage according to Malaysia planning guidelines. Kuala Lumpur has noticeable lost in open space in residential area and this issue might happen with other neighbourhood states such as Negeri Sembilan and Melaka. Therefore, the purpose of this study is to find the resident perspective on the importance of open space while purchasing their housing property. As such, the aim of the research is to study and examine the characteristics of relationship between public open spaces and residential property value using GIS-Hedonic pricing modelling in the selected residential area in Seremban and Melaka. To find the gist of this study, factor analysis has been used to sum the hedonic pricing model output. Seremban and Melaka respondents have chosen the Importance of the House attributes in influencing the house price and Importance of open space following factors in influencing the house price. The research examined the relationship between the open space and house price at selected area in Seremban and Ayer Keroh. As found in the literature reviews, it validates that the relationship established in a positive pattern.
\end{abstract}

Keyword: residential and open space, factor analysis, hedonic pricing model 
M. Zainora Asmawi, Mohammad Abdul Mohit, Norzailawati Mohd. Noor, Alias Abdullah, \& Tuminah Paiman Factor Analysis on Hedonic Pricing Model on Open Space Affecting the Housing Price in Melaka and Seremban

\section{INTRODUCTION}

The opportunity to make open spaces and authenticate environmental sustainability can have significances to liability management, land acquisition, land development and values. Appropriate use of the benefits of green infrastructure lead to substantial economic impacts. Although it has been recognised that it is impossible to comprehensively calculate the economic value of open spaces (Fausold, Charles, \& Liliecholm, 1996), numerous models have been established to offer a framework to measure economic value of open spaces. Value of open spaces expands an area's general sense of attractiveness, helpful to attract visitors, and improve workers' productivity. Creating high quality open spaces also provides an opportunity to make a positive impression and deliver a sense of place that can attract investors and future residents alike. The social value of open space lies in the opportunities it provides for social interaction, social mixing and social inclusion. It can help facilitate the development of community ties and neighbourhood interaction. A public space provides an arena for the exchange of ideas, friendships, goods and skills. Public space is especially important for young children as it gives them play areas, leading to opportunity to make friends and to learn the rules of communal life.

\section{LITERATURE REVIEW}

Plants have unique and collective artistic significance. Plants play an influential role in creating pleasant sceneries, buffering, differentiating and uniting spaces in between residential and industrial areas. Parks and green parks are meant for various recreational activities. Apart from recreational activities, open space also acts as acoustic isolation which buffer unpleasant sound between traffic roads and residential areas. The positive characteristics of open spaces are determinants of environmental factors influencing housing prices. However, economic valuation of the open space benefits is ambiguous as open spaces are public properties without a market price. Open space lacks value, hence it is not being considered in the cost-benefit analysis on the urban planning policies. Economic science has established detailed approaches to capture the value of environmental assets in monetary units. This value is calculated by observing people's behaviour, such as travel cost method. Other approaches such as contingent valuation, gather the value of the environmental asset by asking people about the cost they willing to pay in order to use or conserve the open space (Morancho, 2003).

There are few examples about the effect of open spaces towards house prices. Hui, Chau, Pun and Law (2007) examined the neighbouring and environmental features of a housing property on its market value in a high-rise, densely populated living environment. The results were similar with earlier studies. House owner were keen to pay more for apartments with a better view and better air. Though, green belt was not important variable on housing price. Kong, Yin, and Nakagoshi (2007) calculated the facility value of open space by 
using GIS methods and landscape metrics in hedonic price modelling. As anticipated, the outcomes also established the positive facility impact of proximate open space on house price. Jim and Chen (2010) evaluated the external properties of neighbourhood open space on the transaction price of high-rise housing units in Hong Kong. The result showed that neighbourhood open space could boost the housing price by $16.88 \%$, including $14.93 \%$ for availability and $1.95 \%$ for view (Biao, Gaodi, Bin, \& Canqiang, 2012).

\section{PROBLEM STATEMENT}

Open space has an indirect impact on property prices. The value of trees, water and open space is reflected in house prices (Luttik, 2000). There is a strong case for the preservation of existing green areas in residential areas and the creation of green areas in new urban development (Luttik J, 2000). Burgess, Monk and Whitehead (2007), demonstrated how green spaces enhance residential property values, concluding that different types of residential properties and different open space types affect values in different ways as shown below.

Table 1. How nearby green spaces can enhance property values

\begin{tabular}{lccc}
\hline & Detached & Flat & Non-detached \\
\hline City park & $19.97 \%$ & $7.54 \%$ & $2.93 \%$ \\
Local park & $9.62 \%$ & $7.92 \%$ & $9.44 \%$ \\
Open space & $2.71 \%$ & $4.70 \%$ & $0.44 \%$ \\
\hline
\end{tabular}

Source: RICS, 2007

From high quality open space, open space helps to expand the value of any property near the area. Developers normally look for an opportunity to maximise land values through development. Open space facility creates a sense of place hence contributing to design quality. Undeniably, high quality open spaces in larger developments are used as the main of marketing materials.

\section{AIM AND OBJECTIVES}

The purpose of the research is to learn and observe the relationship between public open spaces and residential property value by using the Hedonic pricing modelling in the selected residential areas located at Seremban, Negeri Sembilan and Ayer Keroh, Melaka. The research objectives are (i) to determine house attributes in influencing the house price and (ii) to identify the importance of open space in influencing the house price.

\section{METHODOLOGY}

A total of 425 houses were identified in Taman Tasik Utama, Ayer Keroh, Melaka (Figure 2) and Taman Pulai Impian, Seremban, Negeri Sembilan (Figure 4). At 95\% confidence level, 207 samples were collected based on $\pm 5 \%$ sample size. Both settlements were carefully chosen based on the following criteria: (i) the 
M. Zainora Asmawi, Mohammad Abdul Mohit, Norzailawati Mohd. Noor, Alias Abdullah, \& Tuminah Paiman Factor Analysis on Hedonic Pricing Model on Open Space Affecting the Housing Price in Melaka and Seremban

areas have been developed for more than ten years; (ii) the areas have been constructed by well-known developers; (iii) the areas have a high density of population; (iv) the areas are located within highly urbanised areas, and (v) the availability of open space within the sites. A $400 \mathrm{~m}$ radius has been drawn from the centre of open spaces as can be seen in Figure 2 and 4 . The survey form was categorized under four sections: profile of respondent; house details; factors influence the house price; and hedonic pricing model in housing price. The study emphasizes on the understanding of house ownership, favourable elements of open spaces and importance of open space provision.

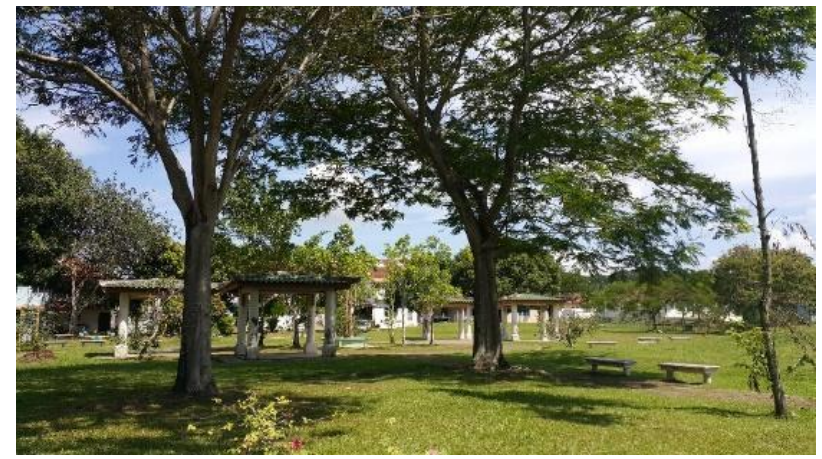

Figure 1: Example of open space that can be found close to the housing vicinity in Taman Tasik Utama. The residential area is 2.863 ha.

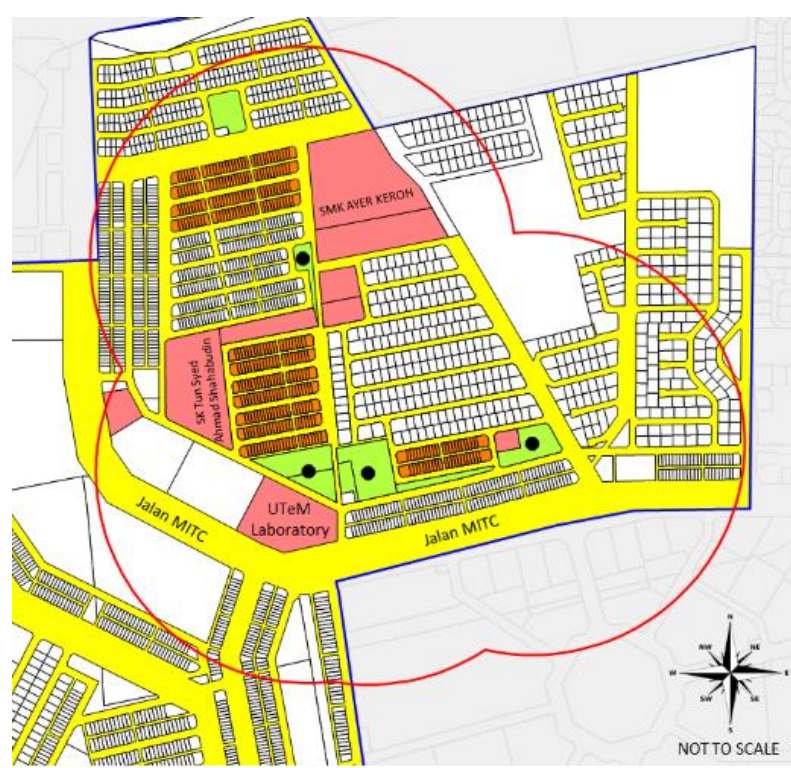

Figure 2: Taman Tasik Utama, Ayer Keroh, Melaka. 
PLANNING MALAYSIA

Journal of the Malaysia Institute of Planners (2018)

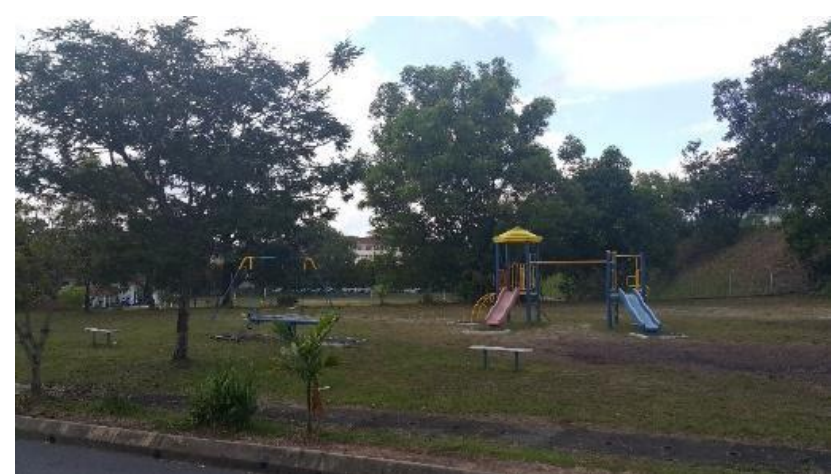

Figure 3: Example of playgound that can be found at Taman Pulai Impian, Seremban.

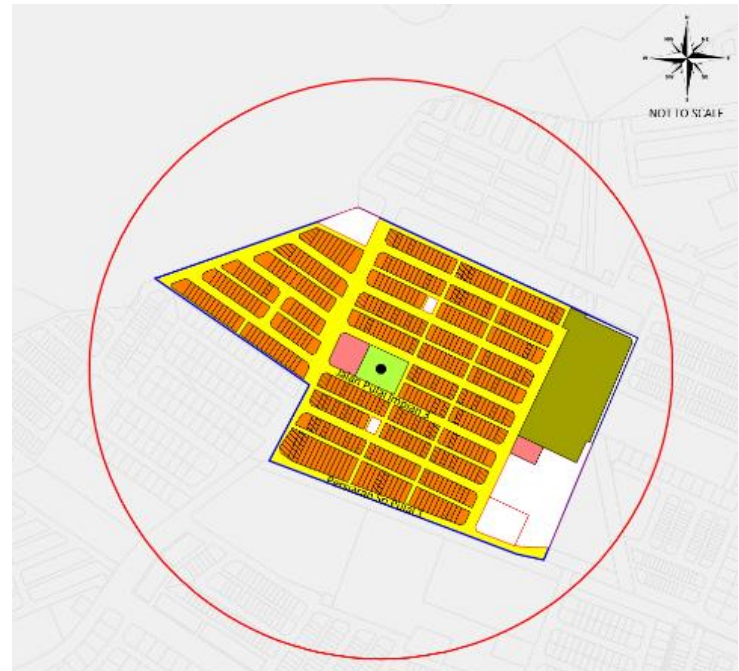

Figure 4: Taman Pulai Impian, Seremban. The residential area has only 1.271ha of open space but it covers the whole $400 \mathrm{~m}$ radius of the residential units

\section{HEDONIC PRICING MODELS}

For this study, Continuous Distance Variables has been used to collect the information for residents at Taman Tasik Utama and Taman Pulai Impian. The hedonic pricing model assess the price of each characteristic that describes a good by connecting the market prices among goods with varied amounts of the attribute. Assume a house consists of a set of varied attributes. The market price of the house can be assumed as the sum of prices for each characteristic defining the house. The function is $\mathrm{P}=f(\chi ! \chi ! \chi !)$ where $P$ is the market price of the house and $\chi !, \chi !, \ldots, \chi$ ! represent the characteristics of which it is formed. The partial derivative of the hedonic price function with respect to a certain characteristic, $\chi$ ! equals the marginal price of that characteristic, which represents the marginal willingness to pay. Housing is essentially good with plenty of 
M. Zainora Asmawi, Mohammad Abdul Mohit, Norzailawati Mohd. Noor, Alias Abdullah, \& Tuminah Paiman Factor Analysis on Hedonic Pricing Model on Open Space Affecting the Housing Price in Melaka and Seremban

characteristics that define it, such as total size and age. The price that the homeowner pays for a house is the sum of the prices of each of its characteristics.

Some of hedonic pricing models can be used to measure the influencing effect of these characteristics on the overall transaction price. These models are developed by using the coefficients generated from a regression analysis. This relationship can be described as 'market price is a function of each tangible and intangible building characteristic and other outside influencing factors' (Thompson, 2002). This is illustrated in the following equation: Market Price $=$ $\mathrm{f}$ (tangible \& building characteristics, other influencing factors). A regression analysis can then be calculated to determine the correlation for each of the characteristics measured against the transaction price. The correlation measurements are then used to create a hedonic pricing model which determine the expected price of the subject property (Thompson, 2002). The hedonic pricing models relies on information provided by households when they make their location decisions (Monson, 2009). The application of the method can be categorized under three heads: 1) wage-amenity studies 2) housing prices; 3 ) valuation of health risks using differences in wages (Monson, 2009; Haripriya \& Vinish, 2004; Ridker \& Henning, 1967) as shown in figure 4 below.

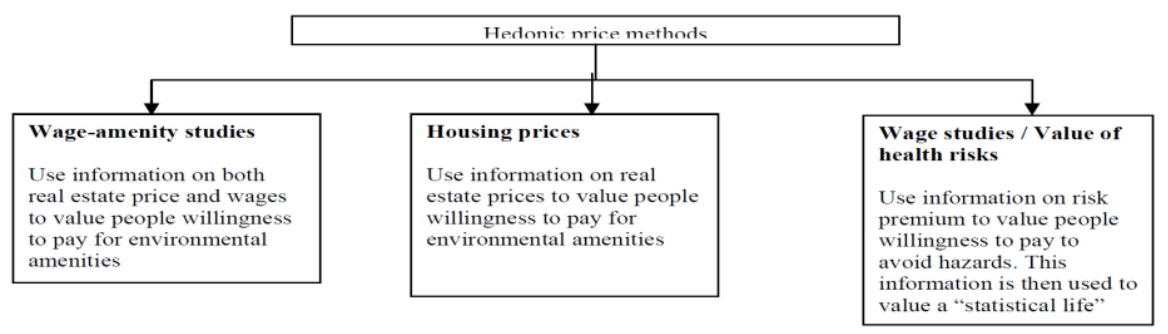

Figure 5: Applications of hedonic price method

\section{ANALYSIS}

207 respondents participated in this study. The samples were collected within the $400 \mathrm{~m}$ radius only. The sample size was sufficient based on the minimum sample size suggested by Sander and Haight (2012) which was 5 sample per variable. A sample size with more than 200 respondents was sufficient to generate the factor analysis. The analysis was generated in three stages, namely (i) descriptive statistics, (ii) reliability analysis and (iii) factor analysis. The dependent variable was the transaction price. 30 independent variables were categorized under three factors. The first factor, 'Factors Influence Housing Price' (HP) consists of eight independent variables which are strategic location, size of built up, attractive house design, provision garage and patio, good view, adequate infrastructure and utilities, adequate open space, road, and transportation network. The second factor, 'Housing Attribute' (Att) comprises of 10 independent variables which are location attraction, lot type end lot, lot type intermediate lot, lot type corner lot, 
PLANNING MALAYSIA

Journal of the Malaysia Institute of Planners (2018)

building condition, construction materials, built up original size, built up after renovation, house age and number of bedroom. The third factor, 'Open Space' (OP) consists of 12 independent variables which are easy access, frequency using open space, reason for going open space, availability active activity, availability passive activity, soft cape quality, adequacy facility, maintenance open space, location strategic, size adequate, facilities suitable to the users and cleanliness well kept.

\section{DESCRIPTIVE STATISTICS}

Descriptive statistics delivered in this study was the frequency and percentages of profiles of respondents. The demographic profiles of respondents were described in terms of gender, age, occupation, monthly income and education level respectively. $56 \%$ of the respondents were male and $44 \%$ were female. The respondents' age ranged between 20 and above 60 years old. Most of the respondents were between 31 and 40 years old (30.4\%) and 41 and 50 years old (29\%). The survey questionnaires were selective towards homeowner or any household members who were knowledgeable about the details of their houses. $37.7 \%$ of the respondents were government workers, followed by private workers $(29.5 \%)$ and self-employed (13\%). Respondents' monthly income level ranged between RM8,001 and RM 12,000 (43.5\%), between RM 5,001 - RM 8,000 $(28.5 \%)$ and less RM 5,000 (13\%). $41.5 \%$ of the respondents have diplomas while $25.6 \%$ of the respondents were bachelor degree holders.

\section{RELIABILITY ANALYSIS}

The research attempts to identify factors in choosing the open space near residential areas among the house owner. Cronbach's Alpha was 0.627 with 28 degree of freedom, indicating internal consistency. The KMO index were 0.60 to 0.69 , thus suggested sample adequacy. The result suggested that the data was reliable for further analysis.

\section{FACTOR ANALYSIS}

Factor analysis was generated to discover the factors in choosing open space near residential area among the house owner at Taman Tasik Utama, Ayer Keroh and Taman Pulai Impian, Seremban residential areas. Bartlett's test of sphericity and the Kaiser-Meyer-Olkin measure of sampling adequacy were used to determine the factorability of the matrix as a whole. Bartlett's test of sphericity was significant $(\mathrm{p}<0.001, \mathrm{p}=0.000)$ as shown in Table 3 . In addition, the KaiserMeyer-Olkin measure was 0.627 which is greater than 0.6 . Based on these result, factorability was assumed (Sander \& Haight, 2012). Factor Analysis was generated to examine factors that affecting a decision of house owners on open space near their property. 
M. Zainora Asmawi, Mohammad Abdul Mohit, Norzailawati Mohd. Noor, Alias Abdullah, \& Tuminah Paiman Factor Analysis on Hedonic Pricing Model on Open Space Affecting the Housing Price in Melaka and Seremban

Table 3: KMO and Bartlett's test

\begin{tabular}{lll}
\hline Kaiser-Meyer-Olkin Measure of Sampling Adequacy. & .627 \\
\hline Bartlett's Test of Sphericity & Approx. Chi-Square & 600.962 \\
\cline { 2 - 3 } & df & 28 \\
\cline { 2 - 3 } & Sig. & .000 \\
\hline
\end{tabular}

The initial communalities represented the relation between the variable and all other variables before rotation. If many or most communalities were low (<.30), a small sample size was more likely to distort results. Table 4 lists 8 factors that had initial communalities above .30, which was good.

Table 4 Communalities

\begin{tabular}{lcc}
\hline & Initial & Extraction \\
\hline Att2 & .612 & .708 \\
Att3 & .614 & .823 \\
OP2 & .451 & .374 \\
OP3 & .514 & .492 \\
OP4 & .601 & .695 \\
OP5 & .549 & .528 \\
OP8 & .233 & .533 \\
OP9 & .247 & .374 \\
\hline
\end{tabular}

Extraction Method: Principal Axis Factoring.

The Total Variance Explained in Table 5 below showed that there were three components with initial Eigenvalues more than 1.0. The first component explained $31.226 \%$ of the total variance, followed by 14.123 and 11.246 respectively.

Table 5 Total Variance Explained

\begin{tabular}{|c|c|c|c|c|c|c|c|}
\hline \multirow{2}{*}{ Factor } & \multicolumn{3}{|c|}{ Initial Eigenvalues } & \multicolumn{3}{|c|}{$\begin{array}{c}\text { Extraction Sums of Squared } \\
\text { Loadings }\end{array}$} & \multirow{2}{*}{$\begin{array}{c}\text { Rotation } \\
\text { Sums of } \\
\text { Squared } \\
\text { Loadings }^{\mathrm{a}} \\
\text { Total }\end{array}$} \\
\hline & Total & $\begin{array}{c}\% \text { of } \\
\text { Variance }\end{array}$ & $\begin{array}{l}\text { Cumulative } \\
\%\end{array}$ & Total & $\begin{array}{c}\% \text { of } \\
\text { Variance }\end{array}$ & $\begin{array}{c}\text { Cumulative } \\
\%\end{array}$ & \\
\hline 1 & $\begin{array}{c}2.89 \\
9\end{array}$ & 36.236 & 36.236 & 2.498 & 31.226 & 31.226 & 2.201 \\
\hline 2 & $\begin{array}{c}1.48 \\
9\end{array}$ & 18.610 & 54.846 & 1.130 & 14.123 & 45.349 & 1.845 \\
\hline 3 & $\begin{array}{c}1.36 \\
9\end{array}$ & 17.109 & 71.955 & .900 & 11.246 & 56.595 & 1.001 \\
\hline 4 & .903 & 11.286 & 83.241 & & & & \\
\hline 5 & .543 & 6.790 & 90.031 & & & & \\
\hline 6 & .340 & 4.254 & 94.285 & & & & \\
\hline 7 & .239 & 2.985 & 97.270 & & & & \\
\hline 8 & .218 & 2.730 & 100.000 & & & & \\
\hline
\end{tabular}


PLANNING MALAYSIA

Journal of the Malaysia Institute of Planners (2018)

a. Extraction Method: Principal Axis Factoring.

b. When factors are correlated, sums of squared loadings cannot be added to obtain a total variance.

The factor Pattern Matrix as listed at Table 6 below contain the coefficients for the linear combination of the variables. A total of 27 items were eliminated because they did not contribute to a simple factor structure and failed to meet a minimum criterion of having a primary factor loading of .3 or above.

Table 6. Pattern Matrix

\begin{tabular}{cccc}
\hline Factor & 1 & 2 & 3 \\
\hline OP4 & .847 & & \\
OP5 & .741 & & \\
OP3 & .646 & & \\
OP2 & .541 & .906 & \\
Att3 & & .824 & .733 \\
Att2 & & & .593 \\
OP8 & & & \\
OP9 & & & \\
\hline
\end{tabular}

a. Extraction Method: Principal Axis Factoring.

b. Rotation Method: Promax with Kaiser Normalization.

c. Rotation converged in 5 iterations.

\section{RESEARCH FINDINGS}

Factors in Influencing the House Price for Seremban and Ayer Keroh

Based on the factor extraction, it was identified that the following factors were important determinants in buying a house. In 'Housing Attribute', the variables were lot type end lot, lot type intermediate lot. The respondents also chosed frequency using open space, reason for going open space, availability active activity, availability passive activity, soft cape quality, maintenance open space, and location strategic as the main criteria. There are two economic contributions of open space. First, open space often increases nearby property values which contribute to greater tax revenue for the municipal council. Second, the area avoids costs associated with providing municipal services to a residential area that might otherwise be located on the site (Moore, Graefe, Gitelson, \& Porter, 1992). Home purchasers are usually prepared to pay more for their property to be located close to open space (National Park Service, 1995). A study by Morancho (2003) found that $77.7 \%$ of home buyers valued natural open space as essential in planning residential areas. However in some cases where parks are poorly maintained, noisy, or congested, these open spaces are unfavourable to the homebuyers. Previous studies (National Park Service, 1995; Morancho, 2003) record that surges in property values also depend on the capability of developers 
M. Zainora Asmawi, Mohammad Abdul Mohit, Norzailawati Mohd. Noor, Alias Abdullah, \& Tuminah Paiman Factor Analysis on Hedonic Pricing Model on Open Space Affecting the Housing Price in Melaka and Seremban

to provide access to open spaces and views facing the open spaces given the difficulty to offer open spaces in the planned residential areas.

\section{House Attributes in Influencing House Price}

When it comes to individual properties, house prices are determined by a combination of many different factors. From the analysis, intermediate lot houses have been chosen as one of highest factor in buying a house. In general, intermediate lot has the lowest price while corner lot house is more expensive since it has more land size compared to the others. Apart from intermediate lot, respondents from Seremban and Ayer Keroh also preferred end lot type of houses among the best choices to invest. There exists a diversity of different housing lot types, and it is important to recognise and understand the differences of each type before purchasing the property. The intermediate lot is the most common lot type because it faces one street. The intermediate lot is situated between houses on the left and right side, facing the street with a plot behind the house. Sometimes there are differences of lot sizes and distances between neighbours. An end lot is a lot sitting in a dead-end street without access to any vehicles. The lots normally have larger plot, less traffic, and more privacy. End lots are typically favoured because of the perceived safety of the street for children and the larger yards. The end lot is highlighted by the real estate agent as a huge positive as it gets more sales price.

\section{Importance of Open Space in Influencing House Price}

Open space can be considered as an outdoor playroom within the housing area. It is where people come to relax and enjoy the urban experience. A place for various activities including entertainment, sport activities, and most importantly a place for walking or sitting-out (Rossi-Hansberg, Sarte, \& Owens, 2010). It is tough to measure the impact of open space on housing values as they are many types of houses and uses of open space, the numerous uses of the adjacent land, and other factors (Crompton, 2001). The respondents selected five characteristics in choosing open space near their residential area. Among the characteristics were frequency using open space, reason for going open space, availability active activity such as badminton and basketball courts, availability passive activity, soft cape quality, maintenance open space, and location strategic. In regard of the characteristics, the provision of high quality open spaces help to establish the character of a new residential area and offer a place for community gatherings and other communal activities (Monson, 2009). There is a $20 \%$ growth in the worth of housing properties adjoining or fronting a passive-use open space. The worth is higher if the open space is large, well maintained and mainly used for passive activities. The worth is lower for properties neighbouring smaller open space or open space that are used for active activities, such as football fields. Finally, the distance from the properties to the the open space also plays a role in 
choosing a housing property. House owners living closer to open space enjoy a more benefit than houses owners living further away from the open space.

\section{CONCLUSION}

The research examines the relationship between the open space and house price at selected area in Seremban and Ayer Keroh. In favour of the literature reviews, the findings indicate the importance of open space availability and accessibility in buying a property. The international practices recommend that the closer the house to an open space, the more expensive the selling value. Consequently, the results gathered on the sites also reflect the same pattern, although the relationship is weak. In the local context, the respondents did not prioritize the aspects of physical planning requirement such as the size and location. They preferred the aspect of park management. The respondents considered availability of active activity, availability of passive activity, soft cape quality, maintenance of open space, and strategic location as important elements to support the quality of open space which then influence the housing prices.

\section{ACKNOWLEDGEMENT}

This work was financially supported by the Ministry of Higher Education under the Fundamental Research Grant Scheme (FRGS) no FRGS/2/2014/SS08/UIAM/02/1.

\section{REFERENCES}

Biao, Z., Gaodi, X., Bin, X., \& Canqiang, Z. (2012). The effects of public green spaces on residential property value in Beijing. Journal of Resources and Ecology, 3(3), 243-252.

Burgess, G., Monk, S., \& Whitehead, C. (2007). The provision of affordable housing through section 106: The situation in 2007. Cambridge, UK: RICS.C.W. Thompson, C. W. (2002). Urban open space in the 21 st century. Landscape and Urban Planning, 60, 59-72.

Fausold, C. J. \& Lilieholm, R. J. (1996). The economic value of open space. Land Lines, September 1996.

Haripriya, G. \& Vinish, K. (2004). Can markets value water scarcity and quality: an analysis using hedonic approach. Project report submitted to the South Asian Network for economic institutions, August 2004.

Hui, E. C. M., Chau, C. K., Pun, L., \& Law, M. Y. (2007). Measuring the neighboring and environmental effects on residential property value: Using spatial weighting matrix. Building and Environment, 42(6), 2333-2343.

John Crompton, J. L. (2001). Perceptions of how the presence of greenway trails affects the value of proximate properties. Journal of Park and Recreation Administration, 19(3), 33-51. 
M. Zainora Asmawi, Mohammad Abdul Mohit, Norzailawati Mohd. Noor, Alias Abdullah, \& Tuminah Paiman Factor Analysis on Hedonic Pricing Model on Open Space Affecting the Housing Price in Melaka and Seremban

Kong, F. H., Yin, H. W., \& Nakagoshi, N. (2007). Using GIS and landscape metrics in the hedonic price modeling of the amenity value of urban green space: A case study in Jinan City, China. Landscape and Urban Planning, 79, 240-252.

Luttik, J. (2000) The value of trees, water and open space as reflected by house prices in the Netherlands. Landscape and Urban Planning, 48(3-4), 161-167.

Monson, M. (2009). Valuation using hedonic pricing models. Cornell Real Estate Review, 7, 62-73.

Moore, R. L., Graefe, A. R., Gitelson, R. J., \& Porter, E. (1992). The impact of railtrails: A study of users and nearby property owners from three trails. Washington, DC: National Park Service.

Morancho, A. B. (2003). Hedonic valuation of urban green areas. Landscape and Urban Planning, 66(1), 35-41.

National Park Service (1995). Economic impacts of protecting rivers, trails and greenway corridors: A resource book. Washington, DC: Author.

Ridker, R. G. \& Henning, J. A. (1967). The determinants of residential property values with special reference to air pollution. The Review of Economics and Statistics, 49(2), 246-57.

Rossi-Hansberg, E., Sarte, P., \& Owens, R. (2010) Housing externalities. Journal of Political Economy, 118(3), 829-858.

Sander, H. A. \& Haight, R. G. (2012). Estimating the economic value of cultural ecosystem services in an urban area using hedonic pricing. Journal of Environmental Management, 113,194-205. 